\title{
Effects of typified propolis on mutans streptococci and lactobacilli: a randomized clinical trial
}

\author{
Efeitos da própolis tipificada nos estreptococcos do grupo mutans e lactobacilos: ensaio clínico randomizado
}

Camillo ANAUATE NETTO ${ }^{1}$; Maria Cristina MARCUCCI ${ }^{2}$; Niraldo PAULINO ${ }^{2}$; Andrea ANIDO-ANIDO ${ }^{1}$; Ricardo AMORE $^{1}$; Sergio de MENDONÇA $^{3}$; Laurindo BORELLI NETO ${ }^{1}$; Walter Antonio BRETZ ${ }^{4}$

1 - Biomaterials Research Group - School of Dentistry - UNIBAN Bandeirante Anhanguera University - São Paulo - SP - Brazil.

2 - Professional Masters Program in Pharmacy - School of Pharmacy - UNIBAN Bandeirante Anhanguera University - São Paulo - SP - Brazil.

3 - Microbiology Research Group - Professional Masters Program in Pharmacy - UNIBAN Bandeirante Anhanguera University - São Paulo - SP - Brazil.

4 - Department of Cariology \& Comprehensive Care - College of Dentistry - New York University - New York-NY - USA.

\begin{abstract}
Objective: The aim of this study was to determine in a randomized, double-blind, placebo-controlled clinical trial the effects of typified propolis and chlorhexidine rinses on salivary levels of mutans streptococci (MS) and lactobacilli (LACT). Methods: One hundred patients were screened for salivary levels of MS >100,000 CFUs/mL of saliva. All patients presented with at least one cavitated decayed surface. Sixty patients met entry criteria. Subjects were adults 18-55 years old. After restoration of cavitated lesions patients were randomized to 3 experimental groups: 1) PROP-alcohol-free $2 \%$ typified propolis rinse (n = 20); 2) CHX- $0.12 \%$ chlorhexidine rinse; 3) PLplacebo mouthrinse. Patients rinsed unsupervised $15 \mathrm{~mL}$ of respective rinses twice a day for $1 \mathrm{~min}$ for 28 days. Patients were assessed for the salivary levels of MS (Dentocult SM) and LACT (Dentocult LB) at baseline, 7-day, 14-day, and at 28-day visits (experimental effects) and at 45-day visit (residual effects). General linear models were employed to analyze the data. Results: PROP was superior to CHX at 14-day and 28-day visits in suppressing the salivary levels of MS ( $<<.05)$. PROP was superior to PL at all visits $(\mathrm{p}<.01)$. The residual effects of PROP in suppressing the salivary levels of MS could still be observed at the 45-day visit, where significant differences between PROP and CHX ( $p<.05)$, were demonstrated. PROP was significantly superior than CHX in suppressing the levels of salivary LACT at the 28-day visit $(\mathrm{p}<.05)$. Conclusion: Typified propolis rinse was effective in suppressing cariogenic infections in caries-active patients when compared to existing and placebo therapies.
\end{abstract}

\section{KEYWORDS}

Randomized clinical trial; Typified propolis; Chlorhexidine; Mutans Streptococci; Lactobacilli.

\section{RESUIMO}

Objetivo: O objetivo deste estudo foi determinar, em um estudo randomizado, duplo-cego, placebo-controlado os efeitos da própolis tipificada e clorexidina sobre os níveis salivares de estreptococos do grupo mutans (EM) e lactobacilos (LACT). Métodos: Cem pacientes foram selecionados para níveis salivares de MS > 100.000 UFC/mL de saliva. Todos os pacientes apresentaram pelo menos uma superfície cariada com cavitação. Sessenta pacientes preencheram os critérios de inclusão. Os indivíduos eram adultos com 18-55 anos de idade. Após a restauração das lesões cavitadas, os pacientes foram randomizados para três grupos experimentais: 1) PROP- bochecho livre de álcool de $2 \%$ de própolis tipificada $(\mathrm{n}=20), 2)$ CHX- bochecho de clorexidina $0,12 \%, 3$ ) PL- bochecho placebo. Os participantes bochecharam sem supervisão $15 \mathrm{~mL}$ dos enxaguatórios duas vezes por dia, durante $1 \mathrm{mi}-$ nuto, durante 28 dias. Os pacientes foram avaliados para os níveis salivares de MS (Dentocult SM) e LACT (Dentocult LB) na linha de base, e após 7 dias, 14 dias, 28 dias (efeitos experimentais) e 45 dias (efeitos residuais). Modelos lineares foram utilizados para analisar os dados. Resultados: PROP foi superior ao CHX nas visitas de 14 dias e de 28 dias na supressão dos níveis salivares de SM $(p<0,05)$. PROP foi superior ao PL em todas as visitas $(\mathrm{p}<0,01)$. Os efeitos residuais de PROP na supressão dos níveis salivares de MS ainda foi observado na visita de 45 dias, onde diferenças significativas entre PROP e CHX ( $p<0,05)$ foram demonstradas. PROP foi significativamente superior a CHX na supressão dos níveis salivares de LACT na visita de 28 dias $(\mathrm{p}<0,05)$. Conclusão: $\mathrm{O}$ enxaguatório de própolis tipificada foi eficaz na supressão de infecções cariogênicas em pacientes com atividade de cárie quando comparado a terapias existentes e ao placebo.

\section{PALAVRAS-CHAVE}

Ensaio Clínico Randomizado; Própolis tipificada; Clorexidina; Estreptococos do grupo Mutans; Lactobacilos. 


\section{INTRODUCTION}

Tluorides and chorhexidine are arguably the 1 most common agents utilized for the prevention of oral diseases. These chemical agents have been available for use to the general population where chlorhexidine, particularly, has been used to promote gingival health for over 45 years [1]. The effectiveness of chlorhexidine rinses in fighting gingivitis has extensive documentation as its efficacy is evident from reports using the methodology of meta-analysis [2]. The use of chlorhexidine mouth rinses in the prevention of dental caries however is contradictory. Clinical evidence on the application of chlorhexidine gels and varnishes for the prevention of dental caries is also inconclusive [3].

Propolis is a resinous matter collected by honeybees from different plant exudates, which is used to seal beehives. At least 200 compounds have been identified in different propolis samples of different botanical geographic origins. The typified propolis has standardized constituents such as: prenylated phenolic acids derived from p-coumaric, including it [4]. The literature on propolis use in dentistry is extensive. There are numerous laboratory and clinical reports of propolis that include: suppression and inhibition of cariogenic [5] and periodontal organisms [6], prevention of respiratory infections [7] and gingival inflammation, [8] inhibitory activity against endodontic pathogens [9], and therapeutic action on oral ulcers [10]. These reports however lack evidence of propolis effectiveness because adequately designed randomized controlled trials have yet to be conducted.

Studies comparing propolis with chlorhexidine solutions have been limited to in vitro studies. These studies have suggested that propolis solutions were equivalent to chorhexidine solutions in inhibiting the mutans streptococci [11]. The primary aim of this investigation was to determine in a randomized, double-blind, placebo-controlled clinical trial the experimental and residual effects of typified propolis and chlorhexidine rinses on salivary levels of the mutans streptococci and lactobacilli.

\section{MATERIALS AND METHODS}

\section{Inclusion/Exclusion Criteria}

One hundred-fifty patients were screened from a patient pool attending the Dental Clinics at Bandeirante Anhanguera University - UNIBAN, São Paulo, Brazil. After signing informed consent approved by the Institutional Review Board (UNIBAN-Protocol N.0038/2007), patients were submitted to eligibility criteria. The main entry criteria for participants was to present with salivary levels of the mutans streptococci $>100,000 \mathrm{CFUs} / \mathrm{mL}$ of saliva and to present with at least one cavitated decayed surface. Additional entry criteria included: the presence of at least 20 teeth, no clinical signs of periodontal disease, age range of 18 to 55 years-old, not being a current smoker, normal saliva secretion rate, not being pregnant, and not making use of any oral topical or systemic medication.

\section{Subject Population/Demographics}

This was a randomized double-blind placebocontrolled clinical trial. Sixty patients met entry criteria. These participants were 18-55 years old of both genders and in good general health. Table 1 depicts demographic and clinical characteristics of study participants. Study groups were well balanced at baseline for demographic variables and for the number of decayed and restored teeth.

Table 1 - Demographics and clinical parameters of study participants at entry

\begin{tabular}{ccccc}
\hline Parameter / Group & Chlorhexidine & Propolis & Placebo & Sig. \\
Age & $41.6(13.4)^{*}$ & $39.4(9.8)$ & $39.0(11.7)$ & ANOVANS \\
Gender & & & & 9 \\
Male & 7 & 8 & 11 & Chi-square Test NS \\
Female & 13 & 12 & & Chi-square Test NS \\
Race & 15 & 13 & 4 & \\
White & 2 & 4 & 2 & ANOVANS \\
Black & 3 & 3 & $4.15(3.41)$ & ANOVA NS \\
Parda & $3.0(3.1)^{\star}$ & $2.9(1.9)$ & $6.6(5.2)$ &
\end{tabular}

${ }^{*}$ mean (standard deviation). 


\section{Treatment Products and Protocol}

After restoration of all cavitated lesions patients were randomized to 3 experimental groups: 1 ) alcohol-free, $2 \%$ typified propolis mouth rinse $(n=20)$. Propolis $2 \%$ rinse was manufactured at the laboratories of the Department of Pharmacology at Federal University of Santa Catarina, Florianópolis, Santa Catarina, Brazil. The formulation included $2 \%$ typified propolis, mint flavor, polioxyethelers, sorbitol, blue color and water; 2) a commercially available $0.12 \%$ chlorhexidine mouth rinse; 3 ) placebo mouth rinse that matched propolis mouth rinse without the active ingredient. Patients rinsed $15 \mathrm{~mL}$ of the experimental rinses twice a day for $1 \mathrm{~min}$ for 28 days. Rinsing was performed in the morning and before bedtime after ordinary oral hygiene procedures. Patients were assessed for the salivary levels of mutans streptococci (Dentocult SM, Orion Diagnostica, Espoo, Finland) and lactobacilli (Dentocult LB, Orion Diagnostica, Espoo, Finland) at baseline, 7-day, 14-day, and at 28-day visits (treatment effects) and at 45day visit (residual effects). All adverse reactions were documented and patient accountability/ continuance criteria were recorded at all visits.

\section{Allocation Concealment}

For allocation of groups a computer-generated list of random numbers was used. Rinses were prepared in dark-bottles, which were consecutively numbered according to the randomization schedule. Participants were randomized to one of the three test colormatched rinses. Study coordinator, examiners and participants were unaware of group allocation. The group identity was generated and kept in Florianópolis, SC, Brazil while the study was conducted in São Paulo, SP, Brazil.

\section{Mutans Streptococci Assay}

The Dentocult SM test was employed to determine the salivary levels of the mutans streptococci. Two thirds of a treated plastic strip was inserted into the mouth and rotated on the surface of the tongue about 10 times. This strip was placed into a culture vial containing a well-mixed bacitracin solution and processed according to the manufacturer's instructions. Interpretation of test scores using a density chart was as follows: $0-1:<100,000 \mathrm{CFU} / \mathrm{mL}$ of saliva, $2:>100,000$ to $<1,000,000 \mathrm{CFU} / \mathrm{mL}$ and, 3: $>1,000,000 \mathrm{CFU} / \mathrm{mL}$.

\section{Lactobacilli Salivary Levels}

The Dentocult LB assay was employed to estimate the levels in saliva of lactobacilli. Saliva collected after stimulation was poured overagar surfaces, ensuring that they are well moistened. Excess saliva was allowed to drain from the slide. The slide was screwed tightly back into the tubeand placed the in an upright position in an incubator $\left(36 \pm 2^{\circ} \mathrm{C}\right)$ for four (4) days. The salivary levels of the lactobacilli were estimated as follows: 0- Non-detectable; 2- 1,000 CFU/ $\mathrm{mL}$ saliva; 3- 10,000 CFU/mL saliva; 4- 100,000 $\mathrm{CFU} / \mathrm{mL}$ saliva; 5- 1,000,000 $\mathrm{CFU} / \mathrm{mL}$ saliva.

\section{Product Satisfaction Questionnaire}

Participants were asked to rank mouth rinses according to taste, breath improvements, nausea symptoms, perception of oral cleaninless, ease to use, and olfatory perception. Participants then ranked each item with scores ranging from 1 (excellent) to 5 (poor) for an overall score based on the range of acceptance for a particular mouth rinse.

\section{Statistical Analysis}

Univariate models were employed to analyze the data of treatment effects between study groups for the salivary levels of cariogenic bacteria. Analysis of co-variance was performed to compare treatment effects for all groups between baseline and 28 days and between baseline and 45 days for the salivary levels of the mutans streptococci and lactobacilli adjusted for age and gender. Chi-square tests were employed to analyze frequency distributions of demographic parameters. ANOVA was employed to estimate differences among study groups at baseline for age, and for the number of decayed and restored teeth. We employed SAS (r). 


\section{RESULTS}

Adverse reactions were reported for the chorhexidine and placebo groups at high frequencies with regards to flavor, burning sensations and alterations of taste. Patient satisfaction and acceptability was highest and excellent for the propolis mouth rinse (74\%) followed by the chlorhexidine (68\%) and placebo (45\%) mouthrinses, respectively.

Analysis of co-variance revealed significant treatment effects from baseline to 28 and 45 days for both propolis ( $<<0.05$ ) and chorhexidine $(\mathrm{p}<0.05)$ groups for the salivary levels of mutans streptococci. These same findings were not observed for the salivary levels of lactobacilli. The propolis mouth rinse was superior to chlorhexidine and placebo rinses at 7-day, 14-day and 28-day visits (treatment effects) in suppressing the salivary levels of the mutans streptococci (Table 2). The chlorhexidine was superior to placebo at 7-day and 14-day visit. The propolis mouth rinse was superior to the placebo rinse at all visits (treatment period) in suppressing the salivary levels of the mutans streptococci. The residual effects of propolis mouth rinse in suppressing the salivary levels of mutans streptococci could still be observed after 17 days of product discontinuation, where significant differences between the propolis rinse and chorhexidine and placebo rinses, were demonstrated.

Very little information is available on the efficacy and superiority of suppression of salivary levels of lactobacilli by means of antimicrobials. The data presented in Table 3 shows that propolis mouth rinse was significantly different than chorhexidine mouth rinse in suppressing the levels of salivary lactobacilli at the 28-day visit.

\section{DISCUSSION}

Upon search of the literature it is apparent that this is the first randomized double-blind placebocontrolled trial on the effects of propolis on cariogenic bacteria. Although there are several in vitro studies confirming the inhibitory activity of propolis against the mutans streptococci and in vivo studies attesting the efficacy of chlorhexidine on the suppression of the mutans streptococci, our study design does not permit comparisons with the existing literature as data is not available with study design and product evaluation similar to our protocol.

Despite the high number of initial decayed and restored teeth present in our study population (Table 1), the propolis and chlorhexidine rinses were effective in suppressing the salivary levels of the mutans streptococci from baseline up to 45 days after a 4-week twice-a-day daily use. Similar results were not found for the placebo group. These results need to be put in perspective as a high number of restorations allows for rapid re-colonization of the mutans streptococci $[12 ; 13]$ and, therefore, had our study design been of a longer duration we are unsure if results presented here would have been extended for a longer period of time.

Group analysis at the various pointvisits revealed superior suppression of the mutans streptococci for the propolis rinse when compared to placebo and chlorhexidine rinse at days 7, 14 and 28. Chlorhexidine rinse was superior to placebo at day-7 and day-14 visits but not at day -28 visit (Table 2). The residual effects of the rinsing protocols clearly show that propolis rinse could sustain suppression of the mutans streptococci after 17 days of rinse discontinuation. Notably, we would have expected chlorhexidine rinse to exert similar effects because of chlorhexidine substantivity.

We are unaware of any clinical studies on the effects of propolis rinses on salivary levels of the lactobacilli. Our study has demonstrated that after 4-week use of propolis rinse a significant suppression of the salivary levels of lactobacilli was evident when compared to chlorhexidine and placebo rinses (Table 3). This is added benefit for the propolis rinse as suppression of lactobacilli is hard to attain as recently shown in comparative studies employing chlorhexidine rinses $[14,15]$. 
Table 2 - Effects of rinses on mutans streptococci salivary levels

\begin{tabular}{|c|c|c|c|c|c|}
\hline Group & Baseline & 7 days & 14 days & 28 days & 45 days \\
\hline Propolis $2 \%(n=20)$ & $2.1(0.3)$ & $1.6(0.5)^{a}$ & $1.3(0.5)^{a, b}$ & $1.2(0.4)^{\mathrm{a}}$ & $1.4(0.5)^{\mathrm{a}}$ \\
\hline Chlorhexedine $0.12 \%(n=20)$ & $2.3(0.5)$ & $1.7(0.6)^{b}$ & $1.8(0.5)^{\mathrm{a}}$ & $1.7(0.7)^{\mathrm{a}}$ & $1.9(0.5)^{\mathrm{a}}$ \\
\hline Placebo $(n=20)$ & $2.2(0.4)$ & $2.2(0.7)^{a, b}$ & $1.9(0.5)$ & $2.6(0.6)^{a}$ & $2.6(0.7)^{\mathrm{a}}$ \\
\hline \multirow[t]{2}{*}{ ANOVAp-value } & 0.177 & 0.008 & 0.001 & 0.000 & 0.000 \\
\hline & \multicolumn{4}{|c|}{ TreatmentPeriod } & Residual \\
\hline
\end{tabular}

a, b - Numbers with same superscripts are significantly different by Tukey's pairwise comparisons.

Table 3 - Effects of rinses on lactobacilli salivary levels

\begin{tabular}{|c|c|c|c|c|c|}
\hline Group & Baseline & 7 days & 14 days & 28 days & 45 days \\
\hline Propolis 2\% (n=20) & $2.9(0.9)$ & $2.8(1.0)$ & $2.5(0.7)$ & $2.5(0.7)^{a}$ & $2.7(0.8)$ \\
\hline Chlorhexedine $0.12 \%(n=20)$ & $3.5(0.9)$ & $3.3(1.1)$ & $3.1(0.8)$ & $3.1(0.8)^{\mathrm{a}}$ & $3.1(0.8)$ \\
\hline $\operatorname{Placebo}(n=20)$ & $2.7(0.9)$ & $2.9(0.8)$ & $2.7(1.0)$ & $3.0(0.9)$ & $3.1(1.0)$ \\
\hline ANOVA p-value & 0.021 & 0.265 & 0.108 & 0.033 & 0.220 \\
\hline & \multicolumn{4}{|c|}{ TreatmentPeriod } & Residual \\
\hline
\end{tabular}

a, b - Numbers with same superscripts are significantly different by Tukey's pairwise comparisons.

Limitations of this study include the non-determination of the power of our sample size prior to the commencement of the study. Although our study groups were well-balanced at baseline for various parameters (Table 1) and the fact that we were able to demonstrate superiority of propolis rinses, no sample size calculations were performed during design of this protocol.

Lastly, our questionnaire survey showed higher acceptance of propolis rinse for various factors when compared to chlorhexidine and placebo rinses. One recent study evaluated the compliance and acceptability of a $5 \%$ propolis rinse [16], and although most subjects reported the unpleasant taste of the rinse, they said they were satisfied with the rinse and would recommend its use by others. Only $24 \%$ of individuals reported difficulties in following the study protocols.

\section{CONCLUSIONS}

Typified propolis rinses may be of value in suppressing cariogenic infections in caries-active patients when compared to existing and placebo therapies.

\section{ACKNOWLEDGMENTS}

This study was supported by grants from FAPESP (No. 2007/53047-3).

\section{REFERENCES}

1. Löe H, Schiött CR, Karring G, Karring T. Two years oral use of chlorhexidine in man. I. General design and clinical effects. J Periodontal Res. 1976;11:135-144.

2. GunsolleyJC. A meta-analysis of six-month studies of antiplaque and antigingivitis agents.J Am Dent Assoc. 2006;137:1649-1657.

3. Autio-Gold J.The role of chlorhexidine in caries prevention. Oper Dent. 2008;33:710-6.

4. Marcucci, M.C. Processo de identificação de tipagens da própolis brasileira. PI 0006272-3. Instituto Nacional da Propriedade Industrial, INPI, Brasil, 2000.

5. Duarte S, Rosalen PL, Hayacibara MF, Cury JA, Bowen WH, Marquis RE, Rehder VL, Sartoratto A, Ikegaki M, Koo H.The influence of a novel propolis on mutans streptococci biofilms and caries development in rats.Arch Oral Biol. 2006; 51:15-22.

6. Santos FA, Bastos EM, Rodrigues PH, de Uzeda M, de Carvalho MA, Farias Lde M, Moreira ES. Susceptibility of Prevotellaintermedia/ Prevotellanigrescens (and Porphyromonasgingivalis) to propolis (bee glue) and other antimicrobial agents.Anaerobe 2002; 8:9-15.

7. Cohen HA, Varsano I, Kahan E, Sarrell EM, Uziel Y. Effectiveness of an herbal preparation containing echinacea, propolis, and vitamin $\mathrm{C}$ in preventing respiratory tract infections in children: a randomized, double-blind, placebo-controlled, multicenter study. ArchPediatrAdolesc Med. 2004;158:217-21.

8. Pereira EM, da Silva JL, Silva FF, De Luca MP, Ferreira EF, Lorentz TC, Santos VR. Clinical evidence of the efficacy of a mouthwash 
containing propolis for the control of plaque and gingivitis: A phase II study. Evid Based Complement Alternat Med. 2011:750249. Epub 2011 Mar 31.

9. Moncla BJ, Guevara PW, Wallace JA, Marcucci MC, Nor JE, Bretz WA. The inhibitory activity of typified propolis against Enterococcus species. Z Naturforsch. 2012;67C:249-56.

10. Samet N, Laurent C, Susarla SM, Samet-Rubinsteen N. The effect of bee propolis on recurrent aphthous stomatitis: a pilot study. ClinOrallnvestig. 2007;11:143-147.

11. Malhotra N, Rao SP, Acharya S, Vasudev B. Comparative in vitro evaluation of efficacy of mouthrinses against Streptococcus mutans, Lactobacilli and Candida albicans.Oral Health Prev Dent. 2011;9:261-8.

12. Sandham HJ, Brown J, Chan KH, et al. Clinical trial in adults of an antimicrobial varnish for reducing mutans streptococci. J Dent Res. 1991;70: 1401-1408.
13. Bretz WA, Rosa OPS. Emerging technologies for the prevention of dental caries. Are current methods of prevention sufficient for the high-riskpatient? Int Dent J. 2011;61 (Suppl. 1):29-33.

14. WikénAlbertsson K, Persson A, van Dijken JW. Effect of essential oils containing and alcohol-free chlorhexidine mouthrinses on cariogenic micro-organisms in human saliva.Acta0dontol Scand. 2012 Oct 22. [Epub ahead of print]

15. Featherstone JD, White JM, Hoover Cl, Rapozo-Hilo M, Weintraub $\mathrm{JA}$, Wilson RS et al. A randomized clinical trial of anti-caries therapies targeted according to risk assessment (caries management by risk assessment).Caries Res. 2012;46:118-29.

16. Pereira, EMR, Mordent CM, Silva FF, De Luca MP, Ferreira EF, Cortes ME et al. Phase II study with mounthrinse containing $5 \%$ of propolis for three-months: compliance, appreciation and acceptability of the product. R Periodontia 2010;20:53-59.

\section{Dr. Camillo Anauate Netto}

(Corresponding author)

Programa de Pós-Graduação em Odontologia

UNIBAN Universidade Bandeirante Anhanguera

Rua Maria Cândida, 1813 - Vila Guilherme

02071-013 São Paulo, SP

Tel: 55(11)2967-9145

Received: 2013 Apr 07

e-mail: anauatenetto@uol.com.br 